\title{
p53 alteration is a common event in the spontaneous immortalization of primary BALB/c murine embryo fibroblasts
}

\author{
Diane M. Harvey and Arnold J. Levine \\ Department of Molecular Biology, Lewis Thomas Laboratory, Princeton University, Princeton, New Jersey 08544-1014 USA
}

It has been shown previously that mutant p 53 can act as an immortalizing gene when cotransfected into primary rat embryo fibroblasts along with a selectable marker. To determine whether a mutation at the p53 locus is a common event in the pathways leading to spontaneous cellular immortalization, 11 clonally derived BALB/c murine embryo fibroblast lines were established by passage on a 3T3 schedule and examined for p53 alterations. By the following criteria, all 11 independently established lines contain at least one mutant allele of p53. Seven of these lines have a PAb240-reactive p53 species and exhibit an extended p53 half-life as determined by pulse-chase analysis. The p53 protein species in a subset of these lines is also capable of complex formation with the constitutive heat shock protein hsc70. p53 cytoplasmic DNAs (cDNAs) from several of these lines have been cloned by reverse transcription of cytoplasmic RNA followed by PCR amplification, and the mutations have been mapped by DNA sequence analysis. Point mutation in conserved domains of p53 appears to be a common alteration in these lines, although one established line carries a 24-bp in-frame deletion of $\mathrm{p} 53$. The remaining four cell lines do not express detectable p53 protein. For each line there is a different molecular event underlying the lack of p53 expression: (1) deletion of at least the first 6 exons of both p53 alleles; (2) expression of a single p53 mRNA encoding a stop codon at amino acid position 173; (3) no detectable p53 mRNA; and (4) greatly diminished expression of p53 mRNA. These findings indicate that $\mathrm{p} 53$ alteration commonly occurs in spontaneously immortalized BALB/c mouse embryo fibroblasts passaged on a 3T3 schedule and, therefore, may be an important event for the immortalization process.

[Key Words: p53 mutations; immortalization; murine embryo fibroblasts]

Received September 3, 1991; revised version accepted October 15, 1991.

Most primary animal cells exhibit a limited life span in culture and eventually undergo senescence, during which time the cells cease to divide with a resultant cellular death (Hayflick and Moorhead 1961; Hayflick 1965). The cellular division potential of any particular culture appears to be dependent on several parameters, including the species from which the cells were isolated and the age of the donor (Schneider and Mitsui 1976; Bierman 1978; Goldstein et al. 1978; Rohme 1981). At some frequency, cells escape senescence and acquire the ability to grow in culture indefinitely, thus becoming immortal. The frequency at which cells escape senescence appears to be species dependent. Whereas rodent cells have been observed to undergo spontaneous immortalization quite efficiently (Todaro and Green 1963; Meek et al. 1977; Curatolo et al. 1984), normal human and avian cells have rarely, if ever, been shown to be capable of spontaneous immortalization (Hayflick 1965; Smith and Pereira-Smith 1990).

A number of studies have suggested that immortalization occurs by selection of rare cells in a population carrying mutations that inactivate genes with growth regulatory of growth-suppressive functions (Kraemer et al.
1986; for review, see Shay et al. 1991). Results from cell fusion experiments have shown that cessation of growth related to senescence is dominant to immortalization, suggesting that inactivation of growth-restraining genes is one mechanism of action during the immortalization process (Bunn and Tarrant 1980; Pereira-Smith and Smith 1981,1983|. Moreover, Pereira-Smith and Smith (1988) have employed cell fusion of various immortal human cell lines to define four different complementation groups for indefinite division in human cells. These results are consistent with the idea that immortalization involves changes at a limited number of specific and identifiable loci.

Because wild-type p53 appears to function in a growthsuppressive manner (Finlay et al. 1989; Baker et al. 1990; Chen et al. 1990; Diller et al. 1990; Michalovitz et al. 1990; Martinez et al. 1991), a reasonable hypothesis to be tested is to determine whether mutations at the p53 locus are a commonly occurring event in the formation of permanent cell lines. Several lines of evidence suggest that p53 mutation may be involved in the process of cellular immortalization. It has been shown previously that mutant p53 cytoplasmic DNAs (cDNAs) or genomic 
clones are capable of immortalizing primary rat cells in culture (Jenkins et al. 1984; Rovinski and Benchimol 1988; Levine et al. 1989). Wild-type p53, on the other hand, does not possess this capability. The overexpression of wild-type $\mathrm{p} 53$ has been found to be antithetical to growth in several tissue culture cell lines (Baker et al. 1990; Chen et al. 1990; Diller et al. 1990; Michalovitz et al. 1990; Martinez et al. 1991). Moreover, p53 mutants increase the plating efficiency (number of G418-resistant colonies produced when transfected along with a neomycin-resistance plasmid) of primary rat embryo fibroblasts three to sevenfold as compared with pBR322 and wildtype p53 controls (Finlay et al. 1989). These results demonstrate that the introduction of mutant p53 into primary rat embryo fibroblasts increases their proliferative capacity and also facilitates the immortalization process (Levine et al. 1989).

Similarly, mutant forms of $\mathrm{p} 53$ can cooperate with an activated oncogene, such as ras, to transform primary rat embryo fibroblasts, whereas the wild-type protein does not (Eliyahu et al. 1984; Parada et al. 1984; Hinds et al. 1989,1990 ). Thus, mutant p53 behaves as an immortalizing gene in a classic transformation assay. In accord with this observation, it has been found that established cell lines from many sources, especially those derived from tumor tissue, carry mutant or otherwise altered alleles of p53 (Wolf et al. 1984; Mowat et al. 1985; BenDavid et al. 1988; Finlay et al. 1988; Baker et al. 1990; Bartek et al. 1990; Lehman et al. 1991). p53 mutation now appears to be one of the most prevalent alterations in human cancer (Baker et al. 1989; Nigro et al. 1989; Takahashi et al. 1989; Chiba et al. 1990; Malkin et al. 1990; Srivastava et al. 1990).

To address directly the question of a possible role for p53 mutation in cellular immortalization, a series of $\mathrm{BALB} / \mathrm{c}$ cell lines were established on a $3 \mathrm{~T} 3$ schedule and the p53 genotype was characterized in these lines. Analysis of p53 proteins, transcripts, cDNAs, and genes in these cell lines indicates that mutation of one or both alleles of p53 is a very common event. Every cell line characterized in this study exhibits some type of alteration in p53 expression, leading to the conclusion that p53 mutation may be important for the process of spontaneous immortalization in this cell type.

\section{Results}

Establishment of immortalized cell lines from primary murine embryo fibroblasts

Murine fibroblasts isolated from 14-day BALB/c embryos were used to derive the immortalized cell lines characterized in this study. Primary cultures were established according to the methods described in Todaro and Green (1963) for spontaneous immortalization of primary murine fibroblasts on a $3 \mathrm{~T} 3$ schedule. Briefly, the primary fibroblasts were seeded at a density of $3 \times 10^{5}$ cells/ 6 $\mathrm{cm}^{2}$ tissue culture dish and were passaged every 3 days at the same density. The cultures were observed to undergo a visible crisis period at approximately passages $7-10$, during which time there was no observed cell growth and the number of cells per plate remained $\leqslant 3 \times 10^{5}$ when counted at each 3 -day interval, owing to increased cellular senescence. The cultures began to recover from crisis around passages 11-12, after which the growth rate of the cells began to increase steadily. Approximately 22 passages were required before the generation time of each independently derived line had stabilized to a nearly constant value that was comparable with or greater than the generation time of the original primary fibroblasts from which they were derived. At this point, the cultures were considered to be immortalized.

Individual colonies from each of the 18 established cell lines were cloned by limiting dilution, grown to confluency, and stored frozen in liquid nitrogen as a control against genotypic change that may occur during prolonged growth periods in culture. Duplicate cultures from 11 of these lines were randomly selected for the analyses that follow.

\section{Established $B A L B / c 3 T 3$ lines are altered for $p 53$ protein expression}

The p53 proteins in 11 of the independently derived clonal cell lines described in the previous section were characterized by their reactions with monoclonal antibodies of differing specificities. $\left[{ }^{35} \mathrm{~S} \mid\right.$ Methionine-labeled proteins from each spontaneously immortalized cell line were immunoprecipitated with PAb421, PAb246, and PAb240 to detect changes in the p53 proteins or their expression, and the immunoprecipitates were analyzed by SDS-PAGE (Fig. 1). PAb421 is a monoclonal antibody directed against the conserved carboxyl terminus of the p53 protein (Harlow et al. 1981). This antibody recognizes wild-type and most mutant forms of p53. PAb246 is a murine-specific and conformation-dependent monoclonal antibody that recognizes wild-type, but generally not mutant, forms of p53 (Tan et al. 1986; Yewdell et al. 1986). PAb240 recognizes many mutant $\mathrm{p} 53$ proteins but not the wild-type antigen in its native conformation (Gannon et al. 1990). Therefore, this panel of antibodies is not only useful for determining the presence or absence of $\mathrm{p} 53$ protein in each cell line but also the conformation state of $\mathrm{p} 53$; that is, proteins that lose the PAb246 epitope with a concomitant gain of the PAb240 epitope may arise by mutation at the DNA sequence level.

As can be seen in Figure 1A, the majority of immortalized cell lines retain a p53 protein species recognizable by PAb421. Cell lines $(10) 1,(10) 3,(10) 6$, and $(10) 7$, however, appear to be null (or nondetectable) for p53 protein expression. This conclusion is strengthened further by the observation that these lines are also PAb246 nonreactive (Fig. 1A), PAb240 nonreactive (Fig. 1B), and PAb242 nonreactive (data not shown). PAb242 is a murine-specific monoclonal antibody that recognizes the amino terminus of p53 (Yewdell et al. 1986). As is the case with PAb421, most murine p53 mutations retain PAb242 epitope reactivity. Thus, these four cell lines appear to express no detectable 553 protein. The lowermolecular-weight species migrating below p53 in some 


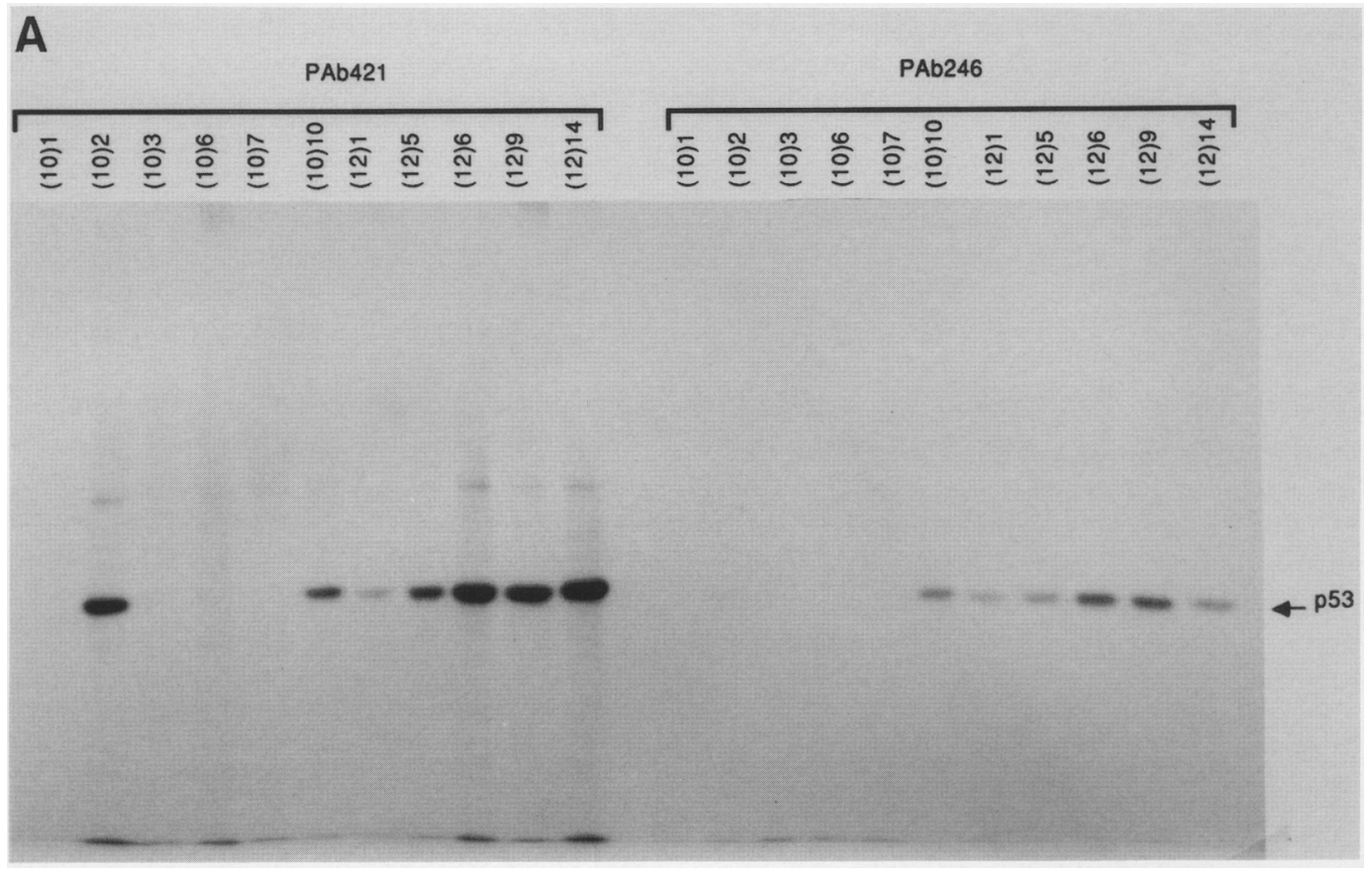

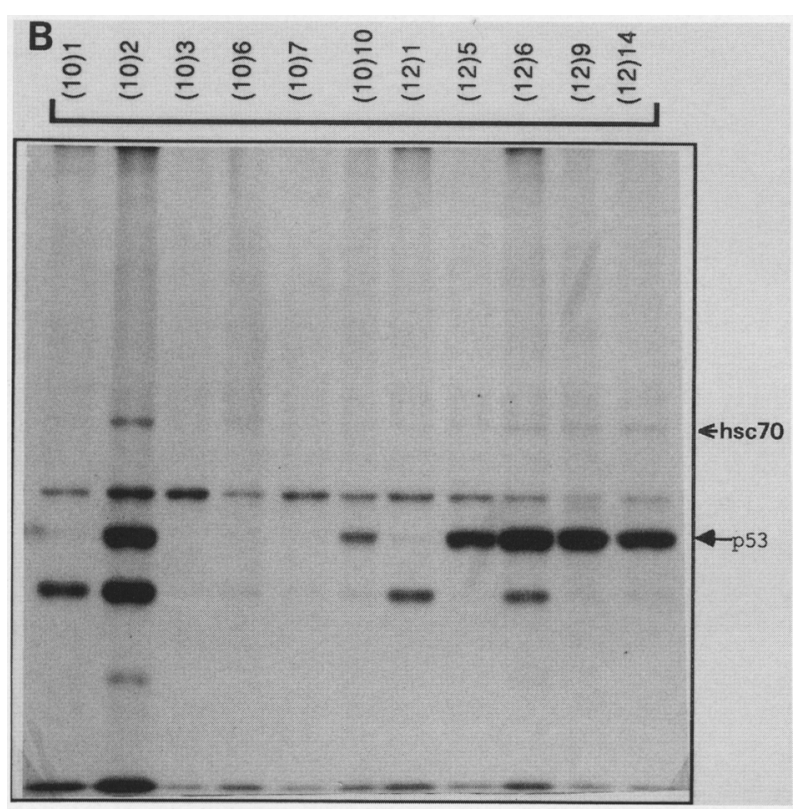

lanes of Figure 1B appears to be unrelated to p53 and is variable from extract to extract.

One cell line, $(10) 2$, expresses p53 protein, as determined by PAb421 reactivity, but has lost the PAb246 epitope. Correspondingly, this cell line is PAb240 reactive, which suggests that only mutant $\mathrm{p} 53$ is expressed in this line. The remaining p53-expressing cell lines [(10)10, $(12) 1,(12) 5,(12) 6,(12) 9$, and (12)14)] produce both PAb246- and PAb240-reactive p53 proteins. The simplest explanation for this result is that each of these cell lines expresses one mutant and one wild-type allele of p53. With the exception of cell line $(10) 10$, this will be confirmed by the protein half-life studies presented in the next section.
Figure 1. (A) Immunoprecipitation of immortalized cell lines with PAb421 and PAb246. Immortalized cell lines were labeled for $2 \mathrm{hr}$ with $\left[{ }^{35} \mathrm{~S} \mid \mathrm{methionine,}\right.$ and equal amounts of trichloroacetic acid (TCA) precipitate counts were analyzed by immunoprecipitation with PAb421 and PAb246. PAb421 is a panspecific monoclonal antibody that detects both mutant and wild-type p53 species. PAb246 is a murine-specific monoclonal antibody that recognizes wild-type, but generally not mutant, p53. The migration position of p53 protein is indicated. $(B)$ Immunoprecipitation of immortalized cell lines with mutant p53 reactive monoclonal PAb240. Immortalized cell lines were labeled for $3 \mathrm{hr}$ with $\left[{ }^{35} \mathrm{~S}\right]$ methionine, and equal amounts of TCAprecipitable counts were analyzed by immunoprecipitation with PAb240 as described in Materials and methods. PAb240 is a pan-specific monoclonal antibody that recognizes many $\mathrm{mu}$ tant p53 proteins but not the wild-type protein in its native conformation. The migration position of $\mathrm{p} 53$ is indicated.

Primary cell culture extracts were also incubated with PAb421 and PAb246 antibodies. It was found that the starting cells for immortalization lineages expressed a p53 protein that reacted with both PAb421 and PAb246, and the observed protein was in low abundance /results not presented). These properties are characteristic of wild-type murine p53 protein. Thus, by immunologic criteria, the primary cell precursors from which the immortalized cell lines were derived appear to express wildtype p53. Thus, the p53 alterations observed in each of the immortalized lines appear to have occurred in concert with the immortalization process.

In summary, it appears that p53 alteration occurs commonly during the spontaneous immortalization of 
BALB/c murine embryo fibroblasts passaged on a $3 T 3$ schedule. In each of the 11 cell lines analyzed, some form of p53 alteration has taken place. Four of the 11 lines express no $\mathrm{p} 53$ protein at all, whereas the remaining cell lines either have one or both alleles of p53 altered immunologically.

\section{Half-life analysis of p53 proteins in immortalized cell lines}

An extension in the half-life of the p53 protein has been shown to be an important indicator of a mutant form of this protein (Reich and Levine 1984; Finlay et al. 1988; Iggo et al. 1990). Previously characterized mutations that activate the 553 protein for immortalization and transformation (by cooperation with another oncogene) often exhibit half-lives of several hours, whereas the half-life of wild-type p53 in primary cells in culture is usually $<30 \mathrm{~min}$. In accord with these observations, a pulsechase analysis was performed on each of the cell lines expressing p 53 to determine the half-lives of the p53 protein species. Figure 2 is an example of such an analysis for cell line $(12) 5$, which contains one wild-type and one

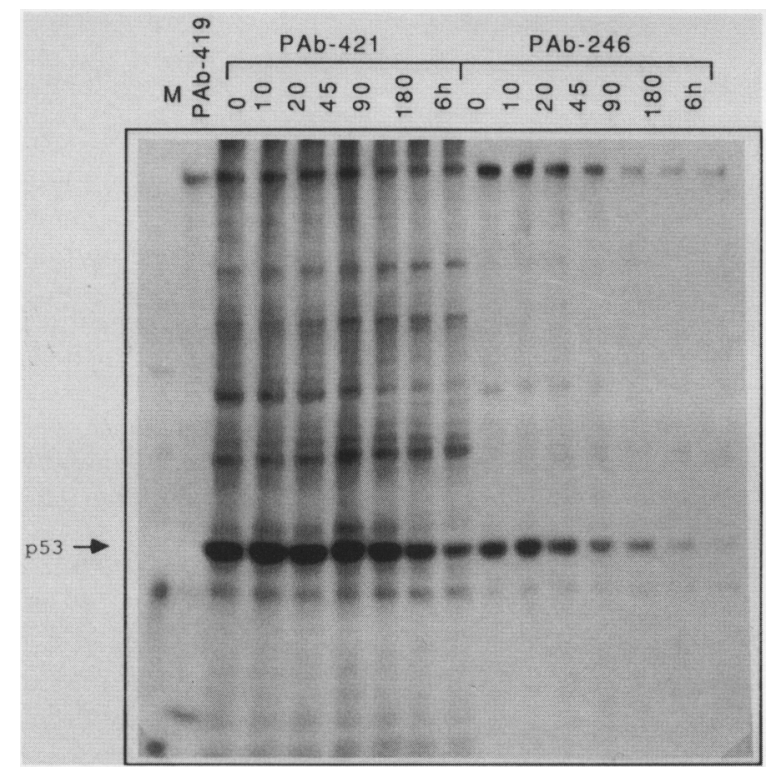

Figure 2. Pulse-chase analysis of cell line (12)5. Cell line (12)5 was pulse-labeled for $\mathrm{l} \mathrm{hr}$ in DMEM plus $2 \%$ dialyzed FCS with $50 \mu \mathrm{Ci} / \mathrm{ml}$ of $\left[{ }^{35} \mathrm{~S} \mid\right.$ methionine. Cells were chased in DMEM plus $10 \%$ FCS with a $2 \mathrm{~mm}$ excess of cold methionine for the following times: $0,10,20,45,90$, and $180 \mathrm{~min}$ and $6 \mathrm{hr}$. Cells were harvested and immunoprecipitations were carried out on equal amounts of TCA-precipitable counts with PAb421 and PAb246. Zero time-point lysate was immunoprecipitated with PAb419 and used as a background control for half-life determination. PAb421 is a pan-specific monoclonal antibody that detects both mutant and wild-type p53 species. PAb246 is a murine-specific monoclonal antibody that recognizes wild-type, but generally not mutant, p53. PAb419 is a monoclonal antibody specific for the large $\mathrm{T}$ antigen of SV40. The migration position of $\mathrm{p} 53$ is indicated. $(M)$ Molecular weight standards. mutant allele of p53 (based on the results in Fig. 1). This idea is supported by the observation that the pulse-labeled p53 protein immunoprecipitated with PAb246 (wild type specific) decays more quickly than the p53 proteins immunoprecipitated with PAb421 (total p53 protein). As outlined in Table 1, the half-life of p53 in cell line $(12) 5$, as determined by immunoprecipitation with $\mathrm{PAB} 421$, is extended relative to the half-life of wildtype p53 in primary BALB/c murine embryo fibroblasts (1.5-2 hr vs. $15-20 \mathrm{~min}$. In contrast, the PAb246-reactive p53 species in $(12) 5$ has a shorter half-life that is comparable with the half-life of wild-type $\mathrm{p} 53$ in cells in tissue culture (15-20 min vs. $30 \mathrm{~min}$ ). This result can be explained by PAb246 recognizing a single short-lived p53 species (wild type) and PAb421 recognizing both shortlived and long-lived protein species (wild type and mutant). Thus, these results support the idea that this cell line expresses both wild-type and mutant p53 proteins.

Figure 3 depicts a pulse-chase analysis of cell line (10)10. This cell line is notable because the turnover of its PAb246-reactive (wild-type conformation) p53 is quite slow. The half-life of this PAb246-reactive p53 species has been measured at $6 \mathrm{hr}$ (Table 1). As mentioned earlier, mutant $\mathrm{p} 53$ proteins described previously have never been recognized by PAb246; therefore, it is surprising to observe such a protein with an increased half-life relative to that of wild-type p53. One possible explanation is that the 553 protein expressed in cell line $(10) 10$ is an example of a p53 mutant that retains the PAb246 epitope. If this is the case, this represents the first example of a dissociation between PAb246 reactivity and a short half-life. The half-life as measured by immunoprecipitation with PAb421 was also determined to be $6 \mathrm{hr}$.

Half-life studies performed on all of the remaining p53-expressing immortalized cell lines indicate that each line contains a p53 species with an extended halflife. Immunoprecipitation of the constitutive heat shock protein hsc70 from each of the immortalized lines, followed by immunoblotting with PAb421, indicates that a subset of these lines express 553 proteins that are capable of forming complexes with hsc70 (see Table 1 and Fig. 1B). Both of these properties (extended half-life and hsc70 complex formation), as well as the presence of the PAb240 epitope have been shown previously to be specific for mutant forms of $\mathrm{p} 53$ (Hinds et al. 1987; Finlay et al. 1988). With the exception of cell line (10)10, each cell line with a PAb246-reactive epitope also expresses a p53 species with a short half-life ( $\leqslant 30 \mathrm{~min}$ ) similar to the wild-type protein in primary cells.

\section{Genetic analysis of p53 in immortalized cell lines}

At this point, the presence of mutations that alter p53 protein expression has been assessed by four criteria: (1) the absence of the PAb246 epitope, for which cell line (10)10 may be an exception; (2) the presence of the PAb240 epitope; (3) complex formation with the constitutive heat shock protein hsc70; and (4) increased halflife. Those mutations that abolish p53 protein expression have been identified by their failure to immunopre- 
Table 1. Properties of immortalized cell lines

\begin{tabular}{|c|c|c|c|c|c|c|}
\hline & $\mathrm{PAb} 421^{a}$ & PAb246a & $\operatorname{PAb} 240^{\mathrm{a}}$ & hsc $70^{b}$ & Half-life & Mutation \\
\hline primary $\mathrm{MEF}^{\mathrm{c}}$ & + & + & ND & ND & $\begin{array}{l}421: \sim 15-20 \mathrm{~min} \\
246: \mathrm{ND}\end{array}$ & \\
\hline$(10) 1$ & 0 & 0 & 0 & NA & $\begin{array}{l}\text { 421: NA } \\
\text { 246: NA }\end{array}$ & large deletion in both alleles \\
\hline$(10) 2$ & + & - & + & + & $\begin{array}{l}421: \sim 3.5-4 \mathrm{hr} \\
246:-\end{array}$ & $\begin{array}{l}\text { single cDNA detected with } 24-b p \text { in-frame deletion } \\
\text { spanning amino acids } 266-273\end{array}$ \\
\hline$(10) 3$ & 0 & 0 & 0 & NA & $\begin{array}{l}\text { 421: NA } \\
\text { 246: NA }\end{array}$ & $\begin{array}{l}\text { single cDNA detected with stop codon (TGC-TGA) at } \\
\text { amino acid position } 173\end{array}$ \\
\hline$(10) 6$ & 0 & 0 & 0 & NA & $\begin{array}{l}\text { 421: NA } \\
\text { 246: NA }\end{array}$ & $\begin{array}{l}\text { diminished transcript levels by Northern analysis; no } \\
\text { protein detectable by immunoprecipitation; base } \\
\text { pairs } 463-1240 \text { have wild-type sequence }\end{array}$ \\
\hline$(10) 7$ & 0 & 0 & 0 & NA & $\begin{array}{l}\text { 421: NA } \\
\text { 246: NA }\end{array}$ & $\begin{array}{l}\text { genes intact by Southern analysis; no RNA by } \\
\text { Northern analysis; no protein by immuno- } \\
\text { precipitation }\end{array}$ \\
\hline$(10) 10$ & + & + & + & - & $\begin{array}{l}421: \sim 6 \mathrm{hr} \\
246: \sim 6 \mathrm{hr}\end{array}$ & $\begin{array}{l}\text { proline to arginine (CCT-CGT) at amino acid } 275 \text {; } \\
\text { second allele contains a } \mathrm{G} \text {-residue insertion at same } \\
\text { position }\end{array}$ \\
\hline$(12) 1$ & + & + & \pm & - & $\begin{array}{l}\text { 421: } \sim 3 \mathrm{hr} \\
246: \cdot\end{array}$ & ND \\
\hline$(12) 5$ & + & + & + & - & $\begin{array}{l}421: \sim 1.5-2 \mathrm{hr} \\
246: \sim 30 \mathrm{~min}\end{array}$ & ND \\
\hline$(12) 6$ & + & + & + & + & $\begin{array}{l}\text { 421: } \sim 2-3 \mathrm{hr} \\
246: 20-45 \mathrm{~min}\end{array}$ & ND \\
\hline$(12) 9$ & + & + & + & + & $\begin{array}{l}\text { 421: } \sim 2.5 \mathrm{hr} \\
246: *\end{array}$ & $\begin{array}{l}\text { lysine to asparagine at amino acid } 129 \text {; second allele } \\
\text { predicted to be wild type by immunoprecipitation }\end{array}$ \\
\hline$(12) 14$ & + & + & + & + & $\begin{array}{l}421: \sim 2.5 \mathrm{hr} \\
246:<30 \mathrm{~min}\end{array}$ & $\begin{array}{l}\text { glutamic acid to glutamine at amino acid } 133 \text {; second } \\
\text { allele predicted to be wild type by immuno- } \\
\text { precipitation }\end{array}$ \\
\hline
\end{tabular}

Abbreviations and symbols: $1+\mid$ Epitope present or hsc70 complex formation competent; $(-1$ epitope absent or failure to form protein complex with hsc70; (0) no detectable p53 protein; (ND) not determined; (NA) not applicable; $\left(^{*}\right)$ specific immunoprecipitation signal is too low to accurately determine half-life.

${ }^{a}$ Denotes whether a given p53 species expresses the respective antibody epitope (antibodies are described in Materials and methods). benotes whether complex formation occurs between the constitutive heat shock protein and a given p53 species.

${ }^{c}$ Murine embryo fibroblasts derived from 14 day BALB/c mouse embryos.

cipitate p53 protein with any of a panel of p53-specific monoclonal antibodies: PAb421, PAb246, PAb240, and PAb242. To determine the genetic basis for the mutations that have occurred in these cell lines, several different genetic analyses have been performed.

A Southern blot analysis was performed on genomic DNA isolated from each of the spontaneously immortalized cell lines. Figure 4 depicts the Southern blot patterns of several lines of particular interest. Most notably, cell line (10)1 appears to contain a large deletion in both alleles of the p53 gene. Two p53-specific bands can be detected in BamHI-digested normal BALB/c genomic DNA of 9.4 and $5.6 \mathrm{~kb}$ (Rotter and Wolf 1985). Line (10)1 is missing the $5.6-\mathrm{kb}$ genomic fragment, which has been shown previously to encode the $5^{\prime}$ region of the p53 gene (Oren 1985). The absence of this region indicates that at least the first 6 exons of both p53 alleles are missing in this cell line. Bands corresponding to this region are also missing in a Southern blot analysis of PstI-digested $(10) 1$ genomic DNA. This large deletion provides an explanation as to why this cell line is null for p53 protein expression. All of the remaining cell lines, including those not shown in Figure 4, generate a wild-type p53 genomic pattern when digested with either enzyme.

The p53 mRNA transcripts in each cell line were characterized by Northern blot analysis (Fig. 5A,B). As expected, the deletion mutant (10)1 cell line does not produce a detectable p53 transcript. Notably, the three other cell lines that are null for p53 protein expression [lines $(10) 3,(10) 6$, and (10)7) appear to express diminished steady-state p53 transcript levels or no p53 transcript at all. The remaining cell lines express easily detectable amounts of p53 transcript similar to the levels found in primary log-phase cells isolated from day-14 BALB/c murine embryo fibroblasts.

To determine the exact nature of the p53 mutations in a number of these cell lines, p53 cDNAs were cloned by reverse transcription of cytoplasmic RNA, followed by polymerase chain reaction (PCR) amplification of $\mathrm{p} 53$ specific sequences. These clones were then characterized by DNA sequence analysis. In most cases, only the cytoplasmic DNA region constituting amino acids 101280 was sequenced, as most activating mutations of p53 have been mapped within this region. It is also important 
Figure 3. Pulse-chase analysis of cell line $(10) 10$. Cell line $(10) 10$ was pulse-labeled for $1 \mathrm{hr}$ in DMEM plus $2 \%$ dialyzed FCS with $50 \mu \mathrm{Ci} / \mathrm{ml}$ of $\left[{ }^{35} \mathrm{~S}\right]$ methionine. Cells were chased in DMEM plus $10 \%$ FCS with a 2 mM excess of unlabeled methionine for the following times: $0,10,20,45,90$, and $180 \mathrm{~min}$ and $6 \mathrm{hr}$. Cells were harvested, and immunoprecipitations were carried out on equal amounts of TCA-precipitable counts using PAb421 and Pab246. Zero time-point lysate was also immunoprecipitated with PAb419 and used as a background control for half-life determination. PAb421 is a pan-specific monoclonal antibody that detects both mutant and wild-type p53 species. PAb246 is a murine-specific monoclonal antibody that recognizes wild-type, but generally not $\mathrm{mu-}$ tant, p53. PAb419 is a monoclonal antibody specific for the large $\mathrm{T}$ antigen of SV40 virus. The migration position of $\mathrm{p} 53$ is indicated. $(M)$ Molecular weight standards.

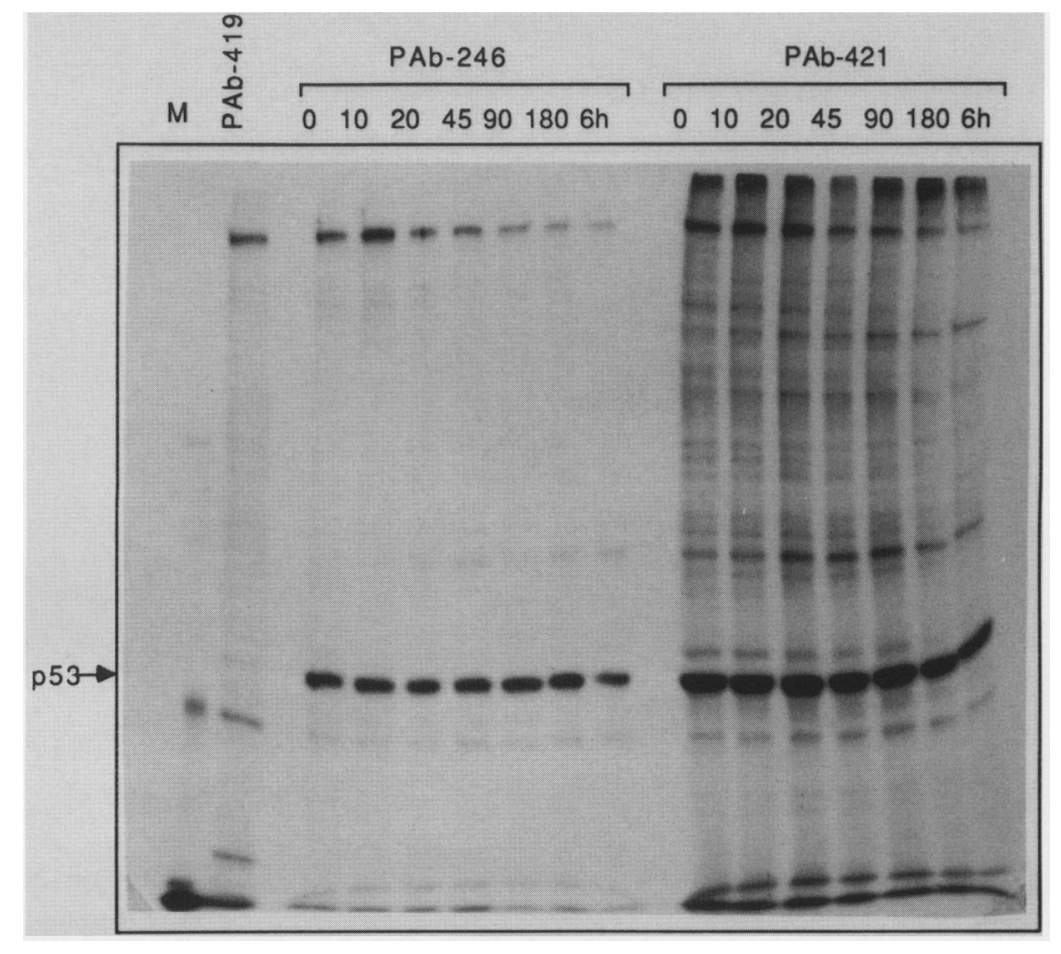

to note that a mutation was considered to be real and not an artifact of the PCR reaction only if the same sequence alteration was detected in at least two independent PCR reactions. The sequencing data are outlined in Table 1 . Most cases of expected mutant p53 protein by the immunoprecipitation and half-life data were found to encode point mutations at the DNA sequence level. Cell line ( 12$) 9$ encodes a lysine-to-asparagine change at amino acid 129, whereas cell line (12)14 encodes a glutamic acid-to-glutamine substitution at amino acid 133. Furthermore, cell line ( 10$) 10$ contains one p53 allele encoding a proline-to-arginine change at amino acid 275. A second p53 allele contains a G-residue insertion at the same position, possibly creating a frame-shift mutation terminating at amino acid 295 in the second allele. The (10)10 cell line has the p53 protein that reacts with PAb246 (wild-type specific) antibody and has a long halflife (6 hr, indicating a mutant protein). It can be concluded, therefore, that that this mutant protein is an exception to the rule that PAb246 only reacts with wildtype $\mathrm{p} 53$ proteins.

Not all of the mutations characterized by sequence analysis were found to be missense mutations. For instance, cell line ( 10$) 3$ appears to express a single p53 RNA species that includes a stop codon at amino acid position 173. Immunoprecipitation of this cell line with PAb242, which recognizes an epitope in the amino terminus of the $\mathrm{p} 53$ protein, failed to detect a truncated $\mathrm{p} 53$ species (data not shown). Two possible explanations for the lack of truncated protein are that the mRNA transcript itself is very unstable and is not translated or that the protein is translated but is again unstable and is degraded quickly. Cell line (10)2 appears to express a single p53 mRNA transcript that encodes a 24-bp in-frame deletion spanning amino acids 266-273. Interestingly, cell line (10)6 contains a wild-type mRNA for all regions of the 53 cytoplasmic DNA clones sequenced (refer to Table 1). As can be seen in Figure 5B, its p53 transcript level is quite diminished in comparison with that detected in log-phase fibroblasts derived from day-14 BALB/c embryos, and this property alone may account for the undetectable p53 protein levels.

\section{When are the p53 mutations detected in these cell lines occurring and selected?}

Finally, it was of some interest to address the question of whether the selection for p53 mutations in each of these cell lines had occurred during cell growth and immortalization or whether cloning of the cells by limiting dilution had placed a selection pressure on these cell lines to obtain mutant p53. Nucleotide sequencing of PCR products indicates that p53 mutation is a result of the immortalization process and is not the result of the added selection placed on the cells during cloning of each established line by limiting dilution. Direct sequencing of PCR products derived from the immortalized, uncloned precursors to clonal cell lines (10)2 and (12)9 indicates that the mutations described for these lines in Table 1 are present in the cellular populations before the cloning step.

\section{Discussion}

When embryonic cells are taken from a mouse and placed in cell culture under favorable growth conditions, 


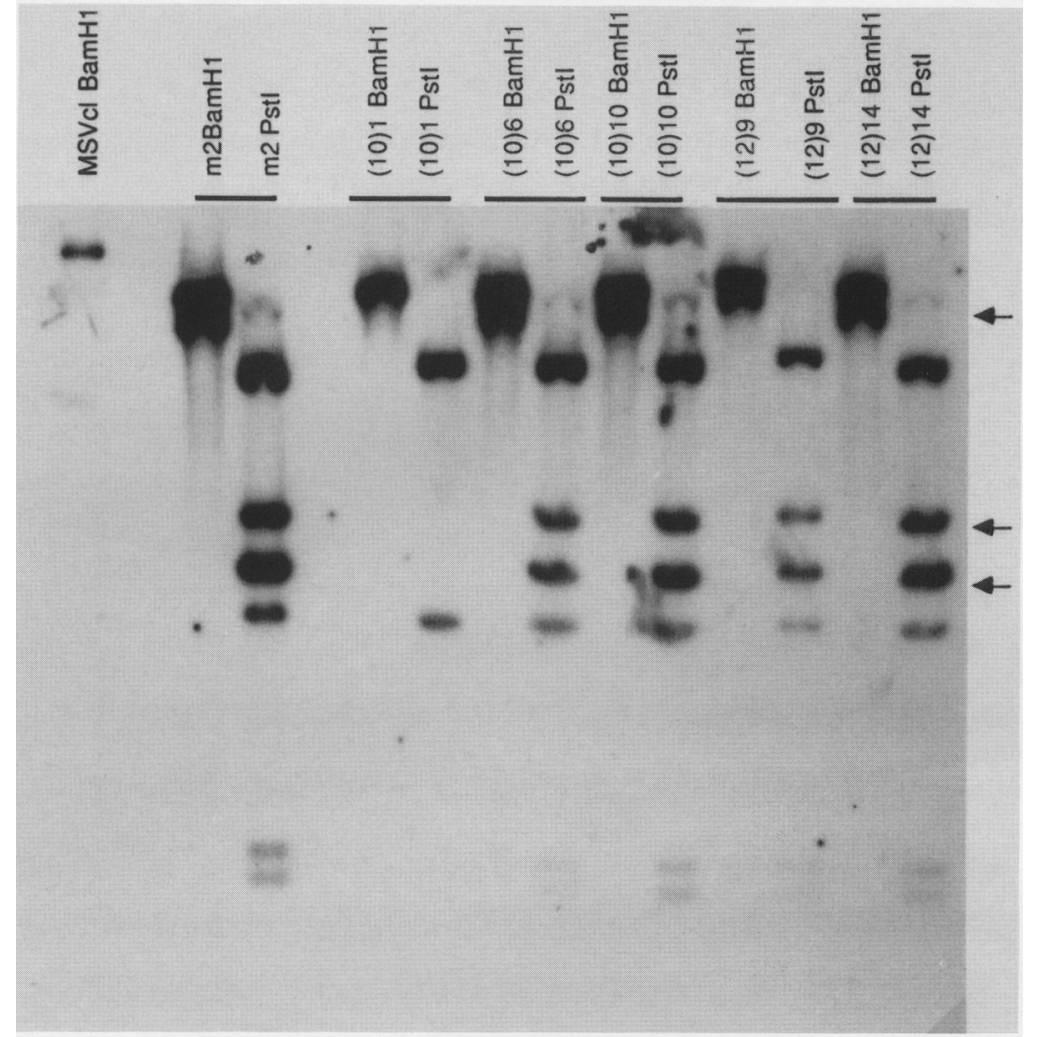

Figure 4. Southern blot analysis of immortalized cell lines. Southern blot analysis was carried out on $10 \mu \mathrm{g}$ of genomic DNA restriction-digested with BamHI and Pstl, as described in Materials and methods. (MSVcl) Ten picogram of a control plasmid containing p53 cDNA sequences; $(\mathrm{m} 2)$ wildtype genomic DNA control derived from mouse liver. Arrows indicate restriction fragments that are not detected in cell line $(10) 1$. the cells divide a limited number of times. The majority of these cells soon cease to proliferate and undergo a process known as senescence. Rare cells grow past this barrier, termed crisis, to form permanent cell lines that are capable of growing in culture indefinitely. Rodent cells have proven to be the most amenable to the study of this process because they immortalize in culture efficiently and spontaneously (Todaro and Green 1963;
Meek et al. 1977; Curatolo et al. 1984). This is in contrast to normal human and avian primary fibroblasts, which have not been observed to immortalize spontaneously in culture (Hayflick 1965; Smith and PereiraSmith 1990). One hypothesis to explain these observations is that the number of mutational events required to confer immortality on rodent cells is fewer than the number required for human and avian cells for the rates

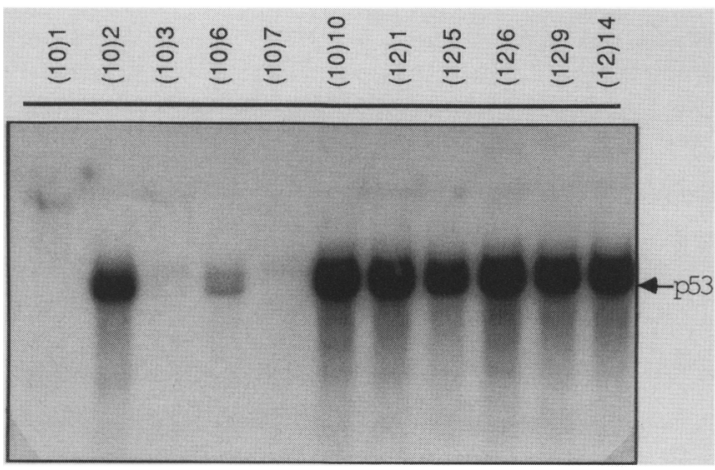

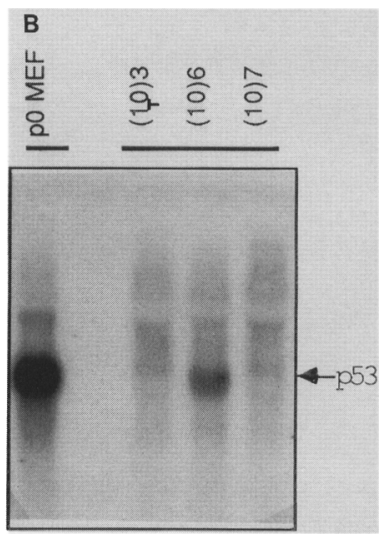

Figure 5. (A) Northern blot analysis of immortalized cell lines. Cytoplasmic RNA was isolated from the indicated immortalized cell lines, and $6 \mu \mathrm{g}$ of each was analyzed by Northern blot analysis, as described in Materials and methods. The arrow indicates the migration position of the 1.83-kb p53 mRNA. (B) Comparison of immortalized cell line p53 transcript levels with those of primary murine embryo fibroblasts. Cytoplasmic RNA was isolated from the indicated immortalized cell lines, and $6 \mu \mathrm{g}$ of each was analyzed by Northern blot analysis as described in $\mathrm{Ma}$ terials and methods. (p0 MEF) Cytoplasmic RNA isolated from a passage 0 culture of primary fibroblasts derived from 14-day $\mathrm{BALB} / \mathrm{c}$ mouse embryos. The arrow indicates the migration position of the $1.83-\mathrm{kb}$ p53 mRNA. 
of mutation are different). Consequently, no one human or avian cell can acquire all of the alterations necessary for indefinite growth before the onset of the crisis period.

Among the cellular genes that might be expected to be targets for selection of a mutant allele are those whose function is to regulate cell growth negatively. The two best studied negative regulators of cell division are the retinoblastoma susceptibility gene $(\mathrm{Rb})$ and the $\mathrm{p} 53$ gene. The results reported in this study test the hypothesis that embryonic mouse fibroblast cells grown in culture collect mutations at the p53 gene locus, which are then selected for, producing immortalized cell lines containing these mutations. To this end, 11 independently derived mouse embryo fibroblast cell lines were obtained. These lines were produced by a $3 \mathrm{~T} 3$ passage schedule $\left(3 \times 10^{5}\right.$ cells transferred every 3 days) that selects for a permanent cell line that does not have many of the other properties of a transformed cell such as low saturation density, failure to grow in agar, and failure to be tumorigenic. Thus, the selection is for a minimal phenotype (i.e., immortality). The status of the p53 gene and gene product were examined in several ways. A series of monoclonal antibodies that recognize the wild-type conformation of the p53 protein (PAb246) (Tan et al. 1986; Yewdell et al. 1986), the mutant conformation of the p53 protein (PAb240) (Iggo et al. 1990), or both forms (PAb421) (Harlow et al. 1981) were used. The half-life of the $\mathrm{p} 53$ protein was determined in each of these cell lines. The wild-type p53 protein has a short half-life 120 $30 \mathrm{~min}$ ), whereas all mutant forms have longer half-lives (Oren et al. 1982; Reich and Levine 1984). The binding of mutant p53 proteins to the heat shock protein hsc 70 was examined (Finlay et al. 1988). Southern blot analysis was used to examine the status of the p53 gene in these cell lines, and Northern blot analysis was used to study the p53 mRNA and its levels. Finally, cDNA copies were made from the p53 mRNAs from these cell lines and selected portions of this cDNA were amplified by PCR. In this way the direct nucleotide sequence of the p53 mRNA was determined in six of these cell lines.

Based on these studies, all 11 cell lines produced in this study carried at least one mutant p53 allele and at least six of these cell lines contained p53 mutations in both alleles. The nature of these mutations were quite diverse: (1) a large deletion of more than half the gene [line (10)1], (2) little or no p53 mRNA [lines (10)6 and (10)7], and (3) a chain termination codon at residue 173 [line (10)3]. These four cell lines failed to synthesize detectable p53 protein. Cell line (10)10 carried mutations in both alleles: a missense mutation at residue 275 and a single-base insertion at residue 275 producing a possible frame shift mutant. Cell line (10)2 appeared to have only a single mutant allele producing an in-frame deletion of 24 bp spanning residues 266-273. These six cell lines selected against both alleles at the p53 locus. Four other cell lines $[(12) 5,(12) 6,\{12) 9$, and $(12) 14\}$ all contain an immunologically wild-type p53 allele and detectable protein. Each of these cell lines also expressed a mutant p53 allele and a missense protein with a long half-life.
Three of these cell lines produced p53 proteins found in a complex with hsc70. These types of mutations could well be trans-dominant where both mutant and wildtype proteins enter the same oligomeric protein complex and the mutant inactivates the function of a wild-type subunit (Finlay et al. 1989). Alternatively, one mutant and one wild-type allele at the p53 locus could result in a lower dosage of a wild-type negative regulator of cell growth in these cells. Finally, the (12)1 cell line that has a PAb246-reactive p53 protein and a PAb421-reactive p53 protein with a half-life of $3 \mathrm{hr}$ has the lowest levels of p53 protein of any cell line in this series that is producing p53 proteins. The levels of PAb246-positive p53 were too low to allow an accurate half-life measurement (see Table 1).

Thus, the pattern emerges from this study that either both p53 alleles are altered, or if one is wild type, a mutant missense protein is selected for and expressed in high levels (longer half-life, higher mRNA levels). This is consistent with the idea that wild-type p53 genes and gene products are selected against when a cell is immortalized in culture. This conclusion, however, should be interpreted in a narrow sense. It should not be generalized to cells from animals of other species (humans, chickens, etc. could be very different) or even other cell types (epithelial cells could be different). It could even be that the selective pressures put on the cell lines in this study come from the protocol employed la 3T3 schedule and cloning by limiting dilution) or other less well-defined variables. It is clear, however, that these p53 mutations arise after the cells are placed in culture, and selection occurs rapidly during cell passage and before cloning. Cell lines $(10) 2$ and $(12) 9$ each contained the same mutant p53 species before and after cloning by limiting dilution. Thus, cells with p53 mutations are selected during replication and passage and enriched in the population before cloning.

There is a strong analogy here between events occurring at the p53 locus in cells in culture and cancers developing in animals. Both situations appear to select against the wild-type p53 gene and product, and both processes often produce p53 missense mutations localized to only a subset of the p53 gene (between codon 120 and 290) (Levine et al. 1991). This common selection for a faulty or altered p53 protein suggests the gain of a new function [even in the absence of a wild-type allele as in line $(10) 2$ and $(10) 10]$, that is, to promote cell growth. It should now be possible to test these ideas more directly.

Finally, this study indicates a significant difficulty in past interpretations of some experiments. Many investigators have carried out nucleotide sequence analysis of the p53 gene or cytoplasmic DNA from cell lines derived from cancer tissues. They then concluded that the cancers contained p53 mutations because the cell lines had these mutations. If p53 mutations are selected for by growing cells in culture, this interpretation will not be a valid one. It will be important to sequence the cDNA products from cancer tissues directly. Furthermore, studies with existing 3T3-like cell lines may need to be reinterpreted in light of the results presented here. 


\section{Materials and methods}

Antibodies

PAb421 is a pan-specific monoclonal antibody that detects both mutant and wild-type p53 from many species (Harlow et al. 1981). PAb246 is a murine-specific and conformation-dependent antibody that recognizes wild-type, but generally not mutant, p53 (Yewdell et al. 1986). PAb240 is a pan-specific monoclonal antibody that recognizes many mutant p53s but not the wild-type protein in its native conformation (Gannon et al. 1990). PAb242 is a murine-specific monoclonal antibody that is directed against the amino terminus of $\mathrm{p} 53$ (Yewdell et al. 1986). PAb419 is a monoclonal antibody specific for the large T-antigen of SV40 virus (Harlow et al. 1981).

\section{Immortalization of primary murine embryo fibroblasts}

Primary murine embryo fibroblasts were isolated from day-14 BALB/c mouse embryos. These primary cells were stored immediately in $90 \%$ FCS and $10 \%$ dimethylsulfoxide (DMSO) and frozen in liquid nitrogen as passage 0 ampules. Two different ampules represent the material used to generate the immortalized murine embryo fibroblast lines described in this paper. The lines beginning with the prefix $(10)$ were derived from one ampule, whereas those lines beginning with the prefix (12) were derived from a second ampule. The cells in each ampule were thawed at $37^{\circ} \mathrm{C}$ and plated in separate $10-\mathrm{cm}^{2}$ tissue culture dishes (Corning, Chicago, Illinois) in Dulbecco's minimal essential medium (DMEM) and $10 \%$ heat-inactivated FCS. At passage 1 , the $(10)$ culture was split into 10 separate $6-\mathrm{cm}^{2}$ tissue culture dishes consisting of $3 \times 10^{5}$ cells each. The same procedure was carried out for the (12) culture, where 12 separate cultures were split into $6-\mathrm{cm}^{2}$ tissue culture dishes at passage 1 . From this point, each of the 22 subcultures was passaged independently on a $3 \mathrm{~T} 3$ schedule according to the specifications of Todaro and Green (1963) to prepare immortal cell lines. Between passages 22 and 24, individual colonies from each of the 18 independent cell lines that recovered from crisis were cloned by limiting dilution to prepare clonal derivatives. Eleven independently derived clonal lines were chosen for further study.

\section{Immunoprecipitations and half-life analyses}

Immunoprecipitations and half-life analyses were performed essentially as described by Hinds et al. (1990), except that cells were starved for methionine for one-half hour before metabolic labeling.

\section{Genomic DNA isolation and Southern blot analysis}

Genomic DNA was isolated by rinsing cultures with PBS, followed by lysing the cells on the plate with $8 \mathrm{ml}$ of lysis buffer [10 mM Tris (pH 8.0), $10 \mathrm{~mm}$ EDTA (pH 8.0), $5 \mathrm{~mm} \mathrm{NaCl}, 0.1$ $\mathrm{mg} / \mathrm{ml}$ of proteinase $\mathrm{K}, 0.5 \% \mathrm{SDS}$. The lysate was incubated overnight at $37^{\circ} \mathrm{C}$ and extracted with buffered phenol, phenolchloroform (1:1), and chloroform. High-molecular-weight DNA was precipitated from the solution by the addition of ammonium acetate up to a $2 \mathrm{M}$ concentration and one volume of ethanol.

Southern blot analysis was carried out on $10 \mu \mathrm{g}$ of genomic DNA restriction-digested with BamHI or PstI essentially according to the method described in Selden (1987a). The EcoRVStuI fragment of p53 cytoplasmic DNA from plasmid p1 1-4 (Tan et al. 1986) was random primed (method of Feinberg and Vogelstein (1983)] and used as a probe.

\section{Cytoplasmic RNA isolation and Northern blot analysis}

Cells were harvested by centrifugation and washed with icecold PBS. Cytoplasmic RNA isolation was according to Farrell et al. (1979).Six micrograms of cytoplasmic RNA isolated from the immortalized murine embryo fibroblasts and from passage 0 primary murine embryo fibroblasts was used for Northern blot analysis essentially as described in Selden (1987b), with the following modifications: (1) Prehybridization and hybridization steps were carried out in Church buffer $\left[0.5 \mathrm{M} \mathrm{Na}_{2} \mathrm{HPO}_{4}(\mathrm{pH}\right.$ 7.21 , 1\% BSA, 7\% SDS, $1 \mathrm{~mm}$ EDTA]; (2) hybridization was carried out at $65^{\circ} \mathrm{C}_{j}(3)$ washes were in $2 \times \mathrm{SSC} / 0.1 \%$ SDS at room temperature for $30 \mathrm{~min}$, followed by an identical wash at $65^{\circ} \mathrm{C}$. The final wash was in $0.2 \times \mathrm{SSC} / 0.1 \%$ SDS at $65^{\circ} \mathrm{C}$ for 40 $\min$.

The probe for Northern blot analysis was $50 \mathrm{ng}$ of randomprimed XhoI-StuI p53 cytoplasmic DNA fragment [method of Feinberg and Vogenstein (1983)] isolated from plasmid pl1-4 (Tan et al. 1986).

\section{PCR amplification and DNA sequencing}

Cytoplasmic RNA was isolated as described above. Complementary DNA was generated in a $20-\mu l$ reverse transcriptase reaction containing the following: $10 \mathrm{mMDTT} ; 1 \times$ reverse transcriptase buffer (supplied as $5 \times$ by Bethesda Research Laboratories, Gaithersburg, Maryland); 40 units of RNasin (Promega Biotech, Madison, WI); 50 pmoles of random hexamers (Promega Biotech, Madison, Wisconsin); 100 units of Moloney murine leukemia virus reverse transcriptase (Bethesda Research Laboratories, Gaithersburg, Maryland); $0.5 \mathrm{~mm}$ dNTPs (Pharmacia, Milwaukee, Wisconsin); and $1 \mu \mathrm{g}$ of cytoplasmic RNA. Reactions were incubated for $10 \mathrm{~min}$ at room temperature and for $35 \mathrm{~min}$ at $42^{\circ} \mathrm{C}$. On completion of the reverse transcriptase reaction, the enzyme was inactivated by heating to $95^{\circ} \mathrm{C}$ for 10 $\min$.

PCR was performed by the addition of the following to the 20- $\mu$ l reverse transcriptase reaction: $10 \mu \mathrm{l}$ of $10 \times$ PCR buffer [500 mM KCl; $200 \mathrm{mM}$ Tris (pH 7.4); $25 \mathrm{mM} \mathrm{MgCl}$; $1 \mathrm{mg} / \mathrm{ml}$ of BSA], 20 pmoles of $5^{\prime}$ and $3^{\prime}$ primers $\left(5^{\prime}\right.$-GCGAATTCCAACTATGGCTTCCACCT-3') and (5'-TACAGAAGAAGAAAATTGAATTCGC-3'), $2.5 \mu \mathrm{l}$ of $10 \mathrm{~mm}$ dNTPs, and 5 units of Taq polymerase (Perkin-Elmer Cetus, Norwalk, CT) to a total volume of $100 \mu l$.

The complementary DNA was amplified by 33 cycles $\{1$ min at $94^{\circ} \mathrm{C}, 2 \mathrm{~min}$ at $55^{\circ} \mathrm{C}$, and $3 \mathrm{~min}$ at $72^{\circ} \mathrm{C}$. This material was gel-isolated and restriction-digested with EcoRI. The PCR fragment was ligated into an EcoRI-cut, phosphatased Bluescript II (Stratagene Cloning Systems, La Jolla, CA) vector. Plasmids carrying inserts were sequenced by the dideoxy chain-termination method (Sanger et al. 1977).

Direct sequencing of PCR products was done as described by Kretz et al. (1989).

\section{Acknowledgments}

We thank James Sherley and Mary Moore for helpful discussions and guidance. Thanks also go to Kate James for her assistance in preparing this manuscript. This work has been supported by a National Institutes of Health training grant 15 T32 GM07312-16).

The publication costs of this article were defrayed in part by payment of page charges. This article must therefore be hereby marked "advertisement" in accordance with 18 USC section 1734 solely to indicate this fact. 


\section{References}

Baker, S.J., E.R. Fearon, J.M. Nigro, S.R. Hamilton, A.C. Preisinger, J.M. Jessup, P. vanTuinen, D.H. Ledbetter, D.F. Barker, Y. Nakamura, R. White, and B. Vogelstein. 1989. Chromosome 17 deletions and $\mathrm{p} 53$ gene mutations in colorectal carcinoma. Science 244: 217-221.

Baker, S.J., S. Markowitz, E.R. Fearon, J.K.U. Willson, and B. Vogelstein. 1990. Suppression of human colorectal carcinoma cell growth by wild-type p53. Science 249: 912-915.

Bartek, J., R. Iggo, J. Gannon, and D. Lane. 1990. Genetic and immunological analysis of mutant p53 in human breast cancer cell lines. Oncogene 5: 893-899.

Ben-David, Y., V.R. Prideaux, V. Chow, S. Benchimol, and A. Bernstein. 1988. Inactivation of the p53 oncogene by internal deletions and/or retroviral integration in erythroleukemic cell lines induced by Friend leukemia virus. Oncogene 3: $179-185$.

Bierman, E.L. 1978. The effect of donor age on the in vitro life span of cultured human arterial smooth muscle cells. In Vitro 14 :951-955.

Bunn, C.L. and G.M. Tarrant. 1980. Limited lifespan of somatic cell hybrids and cybrids. Exp. Cell. Res. 127: 385-396.

Chen, P.-L., Y. Chen, R. Bookstein, and W.-H. Lee. 1990. Genetic mechanisms of tumor suppression by the human p53 gene. Science 250: 1576-1579.

Chiba, I., T. Takahashi, M.M. Nau, D. D'Amico, D.T. Curiel, T. Mitsudomi, D.L. Buchhagen, D. Carbone, S. Piantadosi, H. Koga, P.T. Reissman, D.J. Slamon, E.C. Holmes, and J.D. Minna. 1990. Mutations in the p53 gene are frequent in primary resected non-small cell lung cancer. Oncogene 5: 1603-1610.

Curatolo, L., E. Erba, and L. Morasca. 1984. Culture conditions induce the appearance of immortalized $\mathrm{C}_{3} \mathrm{H}$ mouse cell lines. In Vitro 20: 597-601.

Diller, L., J. Kassel, C.E. Nelson, M.A. Gryka, G. Litwak, M. Gebhardt, B. Bressac, M. Ozturk, S.J. Baker, B. Vogelstein, and S.H. Friend. 1990. p53 functions as a cell cycle control protein in osteosarcomas. Mol. Cell. Biol. 10: 5772-5781.

Eliyahu, D., A. Raz, P. Gruss, D. Givol, and M. Oren. 1984. Participation of p53 cellular tumor antigen in transformation of normal embryonic cells. Nature 312: 646-649.

Farrell, P.J., R.J. Broeze, and P. Lengyel. 1979. Accumulation of an mRNA and protein in interferon-treated Ehrlich ascites tumour cells. Nature 279: 523-535.

Feinberg, A.P. and B. Vogelstein. 1983. A technique for radiola belling DNA restriction endonoclease fragments to high specific activity. Anal. Biochem. 132: 6-13.

Finlay, C.A., P.W. Hinds, T.-H. Tan, D. Eliyahu, M. Oren, and A.J. Levine. 1988. Activating mutations for transformation by p 53 produce a gene product that forms an hsc $70-\mathrm{p} 53 \mathrm{com}$ plex with an altered half-life. Mol. Cell. Biol. 8: 531-539.

Finlay, C.A., P.W. Hinds, and A.J. Levine. 1989. The p53 protooncogene can act as a suppressor of transformation. Cell 57: 1083-1093.

Gannon, J.V., R. Greaves, R. Iggo, and D.P. Lane. 1990. Activating mutations in 53 produce a common conformational effect: A monoclonal antibody specific for the mutant form. EMBO J. 9: 1595-1602.

Goldstein, S., E.J. Moerman, T.S. Soeldner, R.E. Gleason, and D.M. Barnett. 1978. Chronologic and physiologic age affect replicative life-span of fibroblasts from diabetic, prediabetic, and normal donors. Science 199: 781-782.

Harlow, E., L.V. Crawford, D.C. Pim, and N.M. Williamson. 1981. Monoclonal antibodies specific for Simian Virus 40 tumor antigen. J. Virol. 39: 861-869.
Hayflick, L. 1965. The limited in vitro lifetime of human diploid cell strains. Exp. Cell Res. 37: 614-636.

Hayflick, L. and P.S. Moorhead. 1961. The serial cultivation of human diploid cell strains. Exp. Cell Res. 25: 585-621.

Hinds, P.W., C.A. Finlay, A.B. Frey, and A.J. Levine. 1987. Immunological evidence for the association of p53 with a heat shock protein, hsc70, in p53-plus-ras-transformed cell lines. Mol. Cell. Biol. 7: 2863-2869.

Hinds, P., C. Finlay, and A.J. Levine. 1989. Mutation is required to activate the p53 gene for cooperation with the ras oncogene and transformation. J. Virol. 63: 739-746.

Hinds, P.W., C.A. Finlay, R.S. Quartin, S.J. Baker, E.R. Fearon, B. Vogelstein, and A.J. Levine. 1990. Mutant p53 cytoplasmic DNAs from human colorectal carcinomas can cooperate with ras in transformation of primary rat cells. Cell Growth Differ. 1: 571-580.

Iggo, R., K. Gatter, J. Bartek, D. Lane, and A.L. Harris. 1990. Increased expression of mutant forms of p53 oncogene in primary lung cancer. Lancet 335: 675-679.

Jenkins, J.R., K. Rudge, and G.A. Currie. 1984. Cellular immortalization by a cytoplasmic DNA clone encoding the transformation-associated phosphoprotein p53. Nature 312: 651654.

Kraemer, P.M., F.A. Ray, A.R. Brothman, M. Bartholdi, and L.S. Cram. 1986. Spontaneous immortalization rate of cultured Chinese hamster cells. J. Natl. Cancer Inst. 76: 703-709.

Kretz, K.A., G.S. Carson, and J.S. O'Brien. 1989. Direct sequencing from low-melt agarose with Sequenase. Nucleic Acids Res. 17: 5864 .

Lehman, T.A., W.P. Bennett, R.A. Metcalf, J.A. Walsh, J. Ecker, R.V. Modali, S.U. Ullrich, J.W. Romano, E. Appella, J.R. Testa, B.I. Gerwin, and C.C. Harris. 1991. p53 mutations, ras mutations, and p53-heat shock 70 protein complexes in human lung carcinoma cell lines. Cancer Res. 51: 4090-4096.

Levine, A.J., C.A. Finlay, and P.W. Hinds. 1989. The p53 protooncogene and its product. In Common mechanisms of trans formation by small DNA tumor viruses (ed. L.P. Villarreal), pp. 21-37. ASM Publications, Washington, D.C.

Levine, A.J., J. Momand, and C.A. Finlay. 1991. The p53 tumor suppressor gene. Nature 351: 453-456.

Malkin, D., F.P. Li, L.C. Strong, J.F. Fraumeni, Jr., C.E. Nelson, D. Kim, J. Kassel, M.A. Gryka, F.Z. Bischoff, M.A. Tainsky, and S.H. Friend. 1990. Germ line p53 mutations in a familial syndrome of breast cancer, sarcomas, and other neoplasms. Science 250: 1233-1238.

Martinez, J., I. Georgoff, J. Martinez, and A.J. Levine. 1991. Cellular localization and cell cycle regulation by a temperature sensitive p53 protein. Genes \& Dev. 5: 151-159.

Meek, R.L., P.D. Bowman, and C.W. Caniel. 1977. Establishment of mouse embryo cells. Exp. Cell Res. 107: 277-284.

Michalovitz, D., O. Halevy, and M. Oren. 1990. Conditional inhibition of transformation and of cell proliferation by a temperature-sensitive mutant of p53. Cell 62: 671-680.

Mowat, M., A. Cheng, N. Kimura, A. Bernstein, and S. Benchimol. 1985. Rearrangements of the cellular p53 gene in erythroleukaemia cells transformed by Friend virus. Nature 314: 633-636.

Nigro, J.M., S.J. Baker, A.C. Preisinger, J.M. Jessup, R. Hostetter, K. Cleary, S.H. Bigner, N. Davidson, S. Baylin, P. Devilee, T. Glover, F.S. Collins, A. Weston, R. Modali, C.C. Harris, and B. Vogelstein. 1989. Mutations in the p53 gene occur in diverse human tumour types. Nature 342: 705-708.

Oren, M. 1985 . The p53 cellular tumor antigen: Gene structure, expression and protein properties. Biochim. Biophys. Acta 823: $67-78$.

Oren, M., N.C. Reich, and A.J. Levine. 1982. Regulation of the 
cellular p53 tumor antigen in teratocarcinoma cells and their differentiated progeny. Mol. Cell. Biol. 2: 443-449.

Parada, L.F., H. Land, R.A. Weinberg, D. Wolf, and V. Rotter. 1984. Cooperation between gene encoding p53 tumour antigen and ras in cellular transformation. Nature 312: 649-651.

Pereira-Smith, O.M. and J.R. Smith. 1981. Expression of SV40 $\mathrm{T}$-antigen in finite life-span hybrids of normal and SV40transformed fibroblasts. Somatic Cell Genet. 7: 411-421.

1983. Evidence for the recessive nature of cellular immortality. Science 221: 964-966.

- 1988. Genetic analysis of indefinite division in human cells: Identification of 4 complementation groups. Proc. Natl. Acad. Sci. 85: 6042-6046.

Reich, N.C. and A.J. Levine. 1984. Growth regulation of a cellular tumor antigen, p53, in nontransformed cells. Nature 308: 199-201.

Rohme, D. 1981. Evidence for a relationship between longevity of mammalian species and life spans of normal fibroblasts in vitro and erythrocytes in vivo. Proc. Natl. Acad. Sci. 78: 5009-5013.

Rotter, V. and D. Wolf. 1985. Biological and molecular analysis of p53 cellular-encoded tumor antigen. Adv. Cancer Res. 43: 113-141.

Rovinski, B. and S. Benchimol. 1988. Immortalization of rat embryo fibroblasts by the cellular p53 oncogene. Oncogene 2: 445-452.

Sanger, F., S. Nickleu, and A.R. Coulson. 1977. DNA sequencing with chain-terminating inhibitors. Proc. Natl. Acad. Sci. 14: 5463-5467.

Schneider, E.L. and Y. Mitsui. 1976. The relationship between in vitro cellular aging and in vivo human age. Proc. Natl. Acad. Sci. 78: 5009-5013.

Selden, R.F. 1987a. Southern blotting and hybridization. In Current protocols in molecular biology (ed. F.M. Ausubel, R.E. Kingston, D.D. Moore, J.G. Seidman, J.A. Smith, and K. Struhl), pp. 2.9.1-2.9.10., Greene/Wiley-Interscience, New York.

- 1987b. Analysis of RNA by Northern hybridization. In Current protocols in molecular biology (ed. F.M. Ausubel R.E. Kingston, D.D. Moore, J.G. Seidman, J.A. Smith, and K. Struhl), pp. 4.9.1-4.9.8., Greene/Wiley-Interscience, New York.

Shay, J.W., W.E. Wright, and H. Werbin. 1991. Defining the molecular mechanisms of human cell immortalization. Biochim. Biophys. Acta 1072(1): 1-7.

Smith, J.R. and O.M. Pereira-Smith. 1990. Genetic and molecular studies of cellular immortalization. Adv. Cancer Res. 54: 63-77.

Srivastava, S., Z. Zou, K. Pirollo, W. Blattner, and E.H. Chang 1990. Germ-line transmission of a mutated p53 gene in a cancer-prone family with Li-Fraumeni syndrome. Nature 348: 747-749.

Takahashi, T., M.M. Nau, I. Chiba, M.J. Birrer, R.K. Rosenberg, M. Vinocour, M. Levitt, H. Pass, A.F. Gazdar, and J.D. Minna. 1989. p53: A frequent target for genetic abnormalities in lung cancer. Science 246: 491-494.

Tan, T.-H., J. Wallis, and A.J. Levine. 1986. Identification of the p53 protein domain involved in formation of the simian virus 40 large $T$ antigen-p53 protein complex. J. Virol. 59: 574 583.

Todaro, G.J. and H. Green. 1963. Quantitative studies of the growth of mouse embryo cells in culture and their development into established lines. J. Cell. Biol. 17: 299-313.

Wolf, D., S. Admon, M. Oren, and V. Rotter. 1984. Abelson murine leukemia virus-transformed cells that lack p53 protein synthesis express aberrant p53 mRNA species. Mol
Cell. Biol. 4: 552-558.

Yewdell, J., J.V. Gannon, and D.P. Lane. 1986. Monoclonal antibody analysis of p53 expression in normal and transformed cells. J. Virol. 59: 444-452. 


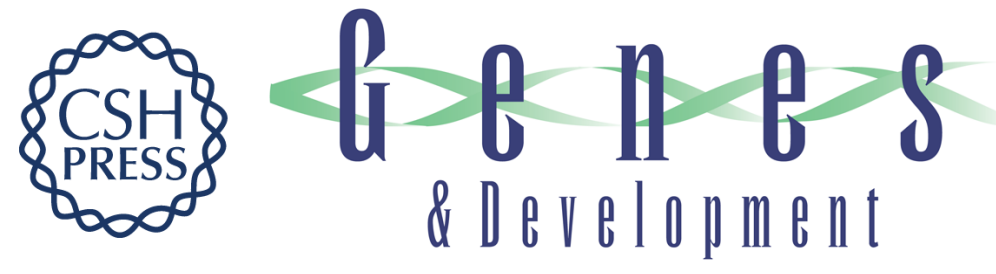

\section{p53 alteration is a common event in the spontaneous immortalization of primary BALB/c murine embryo fibroblasts.}

D M Harvey and A J Levine

Genes Dev. 1991, 5:

Access the most recent version at doi:10.1101/gad.5.12b.2375

References This article cites 55 articles, 21 of which can be accessed free at:

http://genesdev.cshlp.org/content/5/12b/2375.full.html\#ref-list-1

License

Email Alerting

Service

Receive free email alerts when new articles cite this article - sign up in the box at the top right corner of the article or click here.

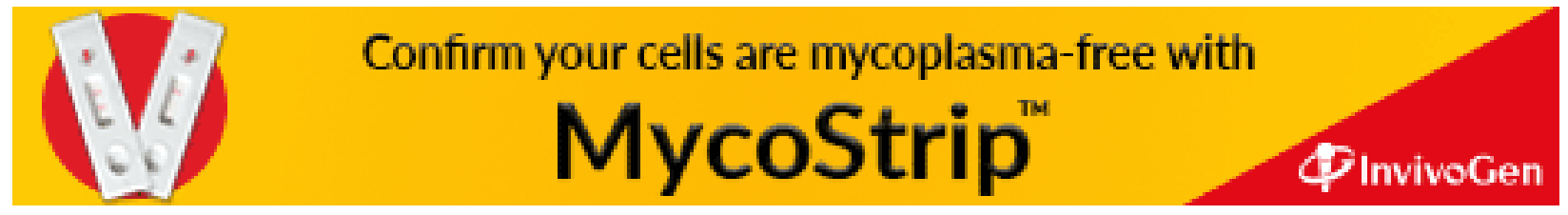

